\section{God norsk innføringsbok til forståelse av rus- og avhengighetsproblematikk}

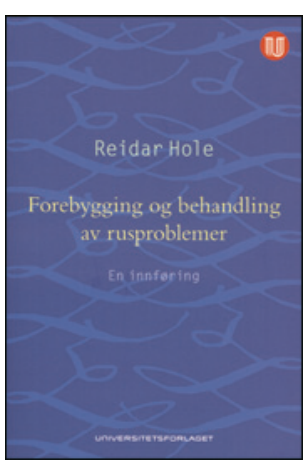

Reidar Hole

Forebygging og behandling av rusproblemer

En innføring. $192 \mathrm{~s}$, tab, ill. Oslo:

Universitetsforlaget, 2014. Pris NOK 299

ISBN 978-82-15-02078-5

Psykolog og tidligere fagdirektør ved Rusbehandling Midt-Norge har skrevet en bok om rus og avhengighetsbehandling. Som leder av Kompetansesenter Rus (KoRus) i Midt-Norge utviklet Reidar Hole senteret til et veldrevet senter med godt omdømme. Han var sentral i Helsedirektoratets arbeid med å lage ny nasjonal retningslinje for behandling av rusmiddelproblemer. Her kom hans store og solide fagkunnskap til god nytte. Hans triste, tidlige dødsfall etterlater seg et tomrom. Holes nyttige lærebok kom ut kun noen få uker før han døde.

Denne boken formidler noe om rus- og avhengighetsproblematikk på en forståelig måte, med passe ydmykhet ovenfor at problemene og kunnskapene er mangslungne, og med god innsikt i hva evidensen sier. Mer kan man ikke forlange av en bok.

Hole sier i innledningen at han henvender seg til studenter, brukere, fagfolk, beslutningstakere og andre interesserte. Utgivelsen vil passe godt for studier på bachelornivå, men kan selvsagt også leses med utbytte av masterstudenter, samt av leger og psykologer. Den omtaler på en god og likefrem måte hvordan bruk, skadelig bruk og avhengighet av rusmidler utvikler seg (tre kapitler), om utbredelsen av bruk og problemer (ett kapittel) og om forebygging og behandling (to kapitler), i tillegg til pårørende, politikk og lover og regler $i$ et avsluttende kapittel. Vi får en innføring $i$ konsekvenser av bruken for den enkelte, men også for familien og samfunnet.

Boken har et klart og lettfattelig språk. Den er velsignet fri for fagspesifikke standpunkter med utgangspunkt i gamle profesjonskonflikter. Den presenterer kunnskap og ikke ståsted, noe som gjør den til en sann bidragsyter til dannelse og utdanning. Hvert kapittel innledes med noen enkle retoriske spørsmål relatert til det resten av kapitlet skal belyse. Og kapitlene leverer på det.

Det er mange gode praktiske eksempler på intervensjoner og administrative tiltak, blant annet eksempler på hva som er individuell plan, og hvordan den skal brukes. Det skrives fint om behandlingsplan og samarbeid mellom ulike institusjoner. Det er noen få, men godt illustrerende figurer og tabeller. Skulle man ønsket seg noe, måtte det være noen enkle intervensjonsgrep som lett kan anvendes.

Det er klart det finnes mer helhetlige og omfattende bøker. Men noen trenger å lese mer kortfattet om dette feltet. Vi trenger derfor slike bøker som Reidar Hole har skrevet, og innenfor det oppdraget forfatteren har gitt seg selv, leveres det bra.

\section{Jørgen G. Bramness}

Direktør, Senter for rus- og avhengighetsforskning (SERAF)

Universitetet i Oslo

\section{Nyttig, men unøyaktig om jus og saksbehandling}

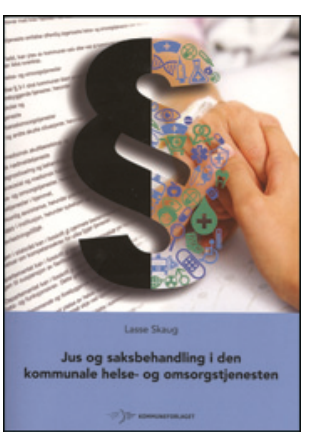

\author{
Lasse Skaug \\ Jus og saksbehandling i den kommunale \\ helse- og omsorgstjenesten \\ 231 s. Oslo: Kommuneforlaget, 2013. \\ Pris NOK 398 \\ ISBN 978-82-446-2124-3
}

Boken omhandler helse- og omsorgstjenesteloven fra 2011. Den er inndelt $\mathrm{i}$ fem deler og omtaler både saksbehandling, kommunens ansvar og plikter, brukerrettigheter, internkontroll og kvalitetsforbedring. Først presenteres hovedtrekkene i «lovreformen», som om dette er noe entydig. Det var to reformer som førte frem til felles lov for helse- og omsorgstjenestene i kommunene, nemlig en reform som samlet helse- og omsorgstjenestene i én felles lov, og samhandlingsreformen.

Forfatteren skiller ikke mellom tildeling og ytelse av helsehjelp. Denne distinksjonen er grunnleggende for å forstå hvilke lover som gjelder: Tildeling (samt inngripende tiltak og klage) følger i hovedsak saksbehandlingsreglene i forvaltningsloven, mens ytelse av helsehjelp og omsorgstjenester - som behandling, pleie og omsorg - reguleres av helsepersonelloven og pasient- og brukerrettighetsloven.

I kapittel 4.4 sier forfatteren at tema for boken er helse- og omsorgstjenester når kommunen fatter enkeltvedtak. Deretter omtales pasientrettighetene. Det burde ha kommet tydeligere frem at pasient- og brukerrettighetsloven primært gjelder mellom den som yter og den som mottar hjelp. Med andre ord, når legen, pleieren o.a. er pliktsubjekt, gjelder pasient- og brukerrettighetsloven. Når saksbehandleren er pliktsubjekt, gjelder forvaltningsloven.

Saksbehandlerne skal primært ha god kjennskap til forvaltningsloven, og det er saksbehandling boken sier at den vil behandle. Forvaltningslovens saksbehandlingsregler gjelder ved enkelte tildelingsvedtak om helsehjelp, helsehjelp til samtykkekompetente pasienter som motsetter seg helsehjelpen, og ved klage.

Taushetsplikten, som mange som arbeider i de kommunale helseog omsorgstjenestene er opptatt av, behandles kun summarisk. Det samme gjelder kapittel 10 om helsehjelp til pasienter og brukere som motsetter seg helsehjelpen. Utgangspunktet om frivillighet og samtykke burde i større utstrekning vært belyst og benyttet som inngang til dette temaet.

Målgruppen for boken er ifølge baksideteksten saksbehandlere i kommunene og helse- og sosialfagstudenter på høyskoler. Etter min mening er den mindre velegnet for den sistnevnte gruppen enn for den førstnevnte. Til å være lærebok på høyskolenivå behandler den for mange vanskelige temaer for summarisk og for overflatisk. Bokens styrke ligger primært $i$ at den bruker praktiske eksempler som illustrasjon. Sånn sett kan den fungere som en håndbok for saksbehandlere i den kommunale helse- og omsorgstjenesten.

Bente Ohnstad

Rektor, Høgskolen i Lillehammer 